\title{
Understanding the Barriers to Defendant Participation in Criminal Proceedings in England and Wales
}

\section{INTRODUCTION}

Over the past two decades, there have been significant developments aimed at securing and enhancing the participation of witnesses in criminal trials. Most notably, the Youth Justice and Criminal Evidence Act 1999 (YJCEA) introduced a statutory scheme for the use of special measures for non-defendant witnesses. The measures, which include screens, live-link and intermediaries, are intended to help vulnerable and intimidated witnesses give their best evidence, while minimising the negative emotional impact of testifying at a criminal trial. ${ }^{1}$ As concern for vulnerable witnesses has increased, additional methods of assistance have been introduced, including ground rules hearings, ${ }^{2}$ pre-recorded crossexamination, ${ }^{3}$ and changes to the rules on cross-examination. ${ }^{4}$ Some of these developments have been extended to vulnerable defendants, yet, the assistance available to them remains inferior to that of vulnerable witnesses. In response, there is a growing body of literature which is critical of the inadequate and unequal treatment of vulnerable defendants in comparison to vulnerable witnesses. ${ }^{5}$ However, there remains comparatively little regard for the fact that many defendants who are not deemed to be 'vulnerable' are unable to participate in criminal proceedings in a meaningful sense. ${ }^{6}$

\footnotetext{
${ }^{1}$ See T Pigot Report of the Advisory Group on Video Evidence (Home Office, 1989); Home Office Speaking up for Justice: Report of the Interdepartmental Working Group on the Treatment of Vulnerable or Intimidated Witnesses in the Criminal Justice System (Home Office, 1998).

2 See generally P Cooper, P Backen, R Marchant 'Getting to grips with ground rules hearings: a checklist for judges, advocates and intermediaries to promote the fair treatment of vulnerable people in court' [2015] Crim LR 420. See also Criminal Procedure Rules (CrimPR) 3.9(7); Criminal Practice Directions 2015 (CPD) [2015] EWCA Crim 1567, General Matters 3E.

${ }^{3}$ Youth Justice and Criminal Evidence Act 1999 (YJCEA), s 28. Note that s 28 is only partially in force.

${ }^{4}$ See, for example, E Henderson 'All the proper protections: the Court of Appeal rewrites the rules for the crossexamination of vulnerable witnesses' [2014] Crim LR 93.

5 See L Hoyano 'Coroners and Justice Act 2009: special measures directions take two: entrenching unequal access to justice?' [2010] Crim LR 345; N Stone 'Special measures for child defendants: a decade of development' (2010) 10 Youth Justice 174; J Talbot Fair Access to Justice? Support for Vulnerable Defendants in the Criminal Courts (Prison Reform Trust, 2012); P Cooper and D Wurtzel 'A day late and a dollar short: in search of an intermediary scheme for vulnerable defendants in England and Wales' [2013] Crim LR 4; J McEwan 'Vulnerable defendants and the fairness of trials' [2013] Crim LR 100; R Arthur 'Giving effect to young people's right to participate effectively in criminal proceedings' (2016) 28 Child and Family Law Quarterly 223; Law Commission Unfitness to Plead (Law Com No 364, 2016); L Hoyano and A Rafferty 'Rationing defence intermediaries under the April 2016 Criminal Practice Direction' [2017] Crim LR 93; S Fairclough 'Speaking up for injustice: reconsidering the provision of special measures through the lens of equality' [2018] Crim LR 4.

${ }^{6}$ See generally J Jacobson, G Hunter and A Kirby Inside Crown Court: Personal Experiences and Questions of Legitimacy (Bristol: Policy Press, 2016).
} 
This article draws attention to the participatory role of all defendants in criminal proceedings. It aims to address two questions. First, why should defendants have participatory rights and be capable of meaningful participation in criminal proceedings? Second, why has it proven so difficult to attain meaningful participation of defendants? The article begins with a brief examination of the key participatory rights held by defendants. Consideration is then given to the rationales for equipping defendants with such rights. Next, attention is turned to the barriers to meaningful participation. The barriers range in nature from the professionalisation and formality of criminal proceedings, to courtroom design, to the restrictive eligibility criteria for special measures. It is contended that barriers to meaningful communication between the defendant and the court will continue to exist until due regard is given to the normative rationales for participatory rights. Instead of being viewed as the subject and key stakeholder of the criminal process, the defendant is often treated as an object on which the criminal law is imposed. Moreover, when defendant participation is valued primarily as a means of increasing efficient fact-finding, as opposed to a mechanism for respecting the autonomy of the defendant and providing a means to challenge the prosecution case, there is little incentive to facilitate meaningful participation.

While this article is concerned with the participatory rights of all defendants, it focuses on contested trials in the Crown Court. This is because the solemnity of Crown Court trials is reflected not only in the maximum sentences for offences triable on indictment, but also in the formality of the proceedings which can, in itself, create a barrier to participation. Nonetheless, most of the issues raised in this article are of direct relevance to trials in the magistrates' courts and also extend beyond the courtroom and contested trials, as there are barriers to participation and meaningful engagement in the police station, pre-trial hearings and sentencing hearings. ${ }^{7}$ With government plans to modernise the court process in ways which could affect participation, ${ }^{8}$ including through greater use of technology, it is a particularly important time to consider the defendant's participatory role. A broader aim of this

\footnotetext{
${ }^{7}$ As well as in other parts of the justice system. See, for example, G McKeever 'A ladder of legal participation for tribunal users' [2013] PL 575.

${ }^{8}$ See, for example, the Lord Chancellor, the Lord Chief Justice, the Senior President of Tribunals Transforming Our Justice System (Ministry of Justice, 2016). See also Guidance: The HMCTS Reform Programme, available at https://www.gov.uk/guidance/the-hmcts-reform-programme (last accessed 17 May 2020).
} 
article is, therefore, to provide material which can be used to assess the defendant's position as a participant during all types of proceedings and at all stages of the criminal process.

As a final preliminary point, it should be noted that the terms 'meaningful participation' and 'effective participation' are used throughout the article. Where the term 'effective participation' is used, it is in reference to the right to effective participation, as guaranteed by Article 6 of the European Convention on Human Rights (ECHR). The right to effective participation includes particular abilities and requirements but, as explained below, its precise scope is uncertain and it has been applied in a restrictive manner. It is, therefore, useful to distinguish this right from 'meaningful participation'. 'Meaningful participation' is employed as a more general term to describe the defendant's ability to: concentrate; follow and understand the proceedings and court process (as and when it unfolds); engage with other participants at the trial; make decisions about the conduct of their case, including whether to give evidence; ${ }^{9}$ do themselves justice in the witness box; and maintain control over the direction and presentation of their case. ${ }^{10}$

\section{PARTICIPATORY RIGHTS}

\section{a. The rights}

Defendants have a right to participate in proceedings against themselves. What may be conceived of as a broad right to participate consists of a number of specific rights, each of which is recognised either expressly or implicitly within the right to a fair trial under Article 6 of the ECHR. These rights include the right to be present at one's trial. ${ }^{11}$ In trials on indictment, there is a requirement to be present, making it somewhat difficult to describe as a 'right'. However, the obligatory nature of attendance in court may be justified on the basis that it is in the defendant's best interest. Presence is a passive form of participation which can ensure that the defendant hears the evidence against them and has an opportunity to follow the proceedings. ${ }^{12}$ It also facilitates active participation by providing the

\footnotetext{
${ }^{9}$ On the importance of decision making capacity, see Law Commission, above $\mathrm{n} 5$.

${ }^{10}$ Subject to the rules of evidence and procedure.

${ }^{11}$ Colozza v Italy (1985) 7 EHRR 516.

12 See $R v$ Lee Kun (1916) 1 KB 337 (CA) 341.
} 
defendant with an opportunity to challenge the prosecution case through, for example, giving evidence or instructing their counsel as the case progresses. ${ }^{13}$ Additionally, the defendant's presence will prevent the jury from drawing an impermissible inference from their absence. ${ }^{14}$ It is, however, possible to proceed in the defendant's absence in the Crown Court, though close regard must be given to the overall fairness of the proceedings. ${ }^{15}$

Beyond the right to be present at trial, the defendant has a 'right to confrontation', ${ }^{16}$ which consists of several participatory rights recognised in Article 6(3) of the ECHR. Article 6(3)(c), for example, provides the defendant with the right to 'defend himself in person or through legal assistance of his own choosing'. Article 6(3)(d) provides the right 'to examine or have examined witnesses against him and to obtain the attendance and examination of witnesses on his behalf under the same conditions as witnesses against him'. The right to examine witnesses may be more appropriately described as an institutional right of the defence, rather than a personal right of the defendant, ${ }^{17}$ since the right can be exercised through the defendant's legal representative. In some circumstances, the defendant is prohibited from personally cross-examining a witness, including where the witness is a complainant of a sexual offence. ${ }^{18}$ Restrictions on personal cross-examination do not contravene the ECHR, as Article 6 does not provide the defendant with a right to physically face their accusers. ${ }^{19}$ However, Article 6(3)(d) does provide support for the defendant's personal right to be heard and to give evidence on their own behalf. ${ }^{20}$

\footnotetext{
${ }^{13}$ To meaningfully participate, the defendant must be capable of both active and passive participation, but active and passive participation at trial can be distinguished. Active participation involves mental effort and physical movement, often resulting in the production of information and the defendant contributing to the trial. Passive participation, on the other hand, requires no direct physical action on the part of the defendant, with the defendant receiving, rather than providing, information.

${ }^{14} \mathrm{H}$ Riddle and S Jones 'Trial in absence in a magistrates' court' [2013] Crim LR 750, 755.

${ }^{15} R v$ Jones [2002] UKHL 5. For a recent application of this principle, see $R v$ Hussain [2018] EWCA Crim 1785.

${ }^{16}$ See generally I Dennis 'The right to confront witnesses: meanings, myths and human rights' [2010] Crim LR 255.

${ }^{17}$ Ibid, p 266.

18 YJCEA 1999, ss 34-36.

${ }^{19}$ See $R$ (on the application of D) $v$ Camberwell Green Youth Court [2005] UKHL 4.

${ }^{20}$ By virtue of $\mathrm{s} 1$ of the Criminal Evidence Act 1898, the defendant is a competent witness for the defence.
} 
The rights to be present and confront the prosecution's case are of limited value to the defendant if they cannot participate effectively. The right to effective participation is an implied Article 6 right. $^{21}$ In the case of $S C \vee U K$, the European Court explained that 'The right of an accused to effective participation in his or her criminal trial generally includes, inter alia, not only the right to be present, but also to hear and follow the proceedings. ${ }^{22}$ The Court went on to explain that:

"effective participation" in this context presupposes that the accused has a broad understanding of the nature of the trial process and of what is at stake for him or her, including the significance of any penalty which may be imposed. It means that he or she, if necessary with the assistance of, for example, an interpreter, lawyer, social worker or friend, should be able to understand the general thrust of what is said in court. The defendant should be able to follow what is said by the prosecution witnesses and, if represented, to explain to his own lawyers his version of events, point out any statements with which he disagrees and make them aware of any facts which should be put forward in his defence. ${ }^{23}$

The defendant's right to legal representation, ${ }^{24}$ and to an interpreter should they need one, ${ }^{25}$ can be necessary to ensure effective participation, as can further assistance in the form of special measures and trial adjustments. ${ }^{26}$ Overall, the right requires the defendant to be able to maintain a level of general understanding and active involvement in their trial. ${ }^{27}$ However, the precise scope of the right is unclear. ${ }^{28}$ For example, it does not explicitly include an ability to give evidence, though this is implicit in the Article 6(3) rights from which the right to effective participation is derived. ${ }^{29}$ It is less apparent whether (or the extent to which) 'effective participation' includes an ability to provide intelligible and

\footnotetext{
${ }^{21}$ Stanford $v$ UK App no 16757/90 (ECHR, 23 February 1994). See also Tv UK (2000) 30 EHRR 121; SC v UK (2005) 40 EHRR 10.

${ }^{22} S C v U K$, above $\mathrm{n} 21$, at [28].

${ }^{23}$ Ibid, at [29].

${ }^{24}$ European Convention on Human Rights (ECHR), Article 6(3)(c).

${ }^{25}$ ECHR, Article 6(3)(e).

${ }^{26}$ Discussed below.

${ }^{27}$ Law Commission, above n 5, para 3.21.

${ }^{28}$ See generally A Owusu-Bempah 'The interpretation and application of the right to effective participation' (2018) 22 International Journal of Evidence and Proof 321.

${ }^{29}$ See Stanford $v$ UK, above n 21, at [26].
} 
coherent testimony. ${ }^{30}$ Also, it is not clear where the boundary lies between being unable to participate effectively and being 'unfit to plead'. ${ }^{31}$ The concept of 'effective participation' is, therefore, in need of further clarification. ${ }^{32}$ Moreover, considering the restrictive way in which the right has been approached by the courts, there may be many defendants who are deemed able to participate effectively, yet cannot give evidence, follow proceedings or engage with other court users in a meaningful way. For example, it has been suggested that the defendant's right to hear and follow the proceedings can be exercised through their lawyer, even where the defendant wishes to exercise the right for themselves. ${ }^{33}$ Before examining the barriers to meaningful participation, it is necessary to consider why participatory rights are important.

\section{b. The rationales}

Having outlined the key participatory rights of the defendant, we now turn to the rationales for these rights. The focus of this section is the broad justifications for equipping defendants with participatory rights, and not the specific rationales for each individual right. The starting point is normative, considering why the defendant should have participatory rights. Attention is then turned to the instrumental value that defendant participation can have for the prosecution and the state. As will be shown, prioritising some of the perceived instrumental benefits of participation can undermine the normative rationales for participatory rights, resulting in the continuation of barriers to meaningful participation.

The defendant is the focal point and key stakeholder in the criminal process. It is the defendant's behaviour that is in issue and they who will face sanctions, if convicted. In accordance with Kantian principles, each individual must be treated with dignity; as an end in themselves and not simply as a means to an end. ${ }^{34}$ The defendant should, therefore, be treated as the subject of proceedings, and not as

\footnotetext{
30 Owusu-Bempah, above n 28, pp 326-328.

31 On the unclear distinction between effective participation and fitness to plead, and its implications, see OwusuBempah, above n 28, pp 328-331.

32 As is the concept of fitness to plead. See Law Commission, above $\mathrm{n} 5$.

33 See Stanford $v$ UK, above n 21; R v Hamberger [2017] EWCA Crim 273. This issue is discussed further below.

34 See I Kant Groundwork of the Metaphysics of Morals (Cambridge: Cambridge University Press, 1996).
} 
an object for condemnation and punishment. To be treated with dignity includes being treated as an autonomous individual. ${ }^{35}$ This then gives rise to an obligation to try to empathetically engage with the defendant's experience and allow them to express their perspective. ${ }^{36}$ Thus, in the context of criminal proceedings, the defendant is intrinsically worthy of dialogue and the criminal trial should attempt to engage them in such. ${ }^{37}$ To engage the defendant in a dialogue, and best realise that the defendant is the autonomous subject of the proceedings, the defendant must have the right and opportunity to be heard and to respond to the accusations made against them. Moreover, serious consideration must be given to whatever the defendant has to say.

This conception of the purpose of participatory rights draws from the work of Ho. Ho proposes that trials should not merely be understood as a means of bringing criminals to justice, but more importantly, as a matter of doing justice to the accused. ${ }^{38}$ Doing justice to accused persons is a political obligation owed by the state to the citizens it seeks to censure and punish. It is owed in order to uphold principles of liberal democracy, including autonomy, and to prevent the oppression of a 'police state'. ${ }^{39}$ According to Ho:

The value of participation, the ability to control and influence one's case, lies in the intrinsic value of self-direction ... independently of its contribution to the probabilities of reaching the correct verdict. Citizens are not objects to be acted upon and kept away by the state for the sake of public safety and order; they are individuals that bear rights against the state in the process that seeks their conviction and punishment. ${ }^{40}$

Duff et al. also advance a conception of the criminal trial based on communication with the defendant. ${ }^{41}$ For them, the criminal trial is, at least in ambition, 'a communicative process in which the defendant

$35 \mathrm{C}$ McCrudden 'Human dignity and judicial interpretation of human rights' (2008) 19 European Journal of International Law 655, 659-660. Kant in particular has become closely affiliated with the idea of dignity as autonomy. See Kant, above n 34 .

36 C MacKenzie 'Relational autonomy, normative authority and perfectionism' (2008) 39 Journal of Social Philosophy 512, 516.

${ }^{37}$ HL Ho 'Liberalism and the criminal trial' [2010] Singapore Journal of Legal Studies 87, 105.

38 Ibid.

${ }^{39}$ Ibid, p 99.

${ }^{40}$ Ibid, $p 100$.

${ }^{41}$ A Duff, L Farmer, S Marshall and V Tadros The Trial on Trial 3: Towards a Normative Theory of the Criminal Trial (Oxford: Hart Publishing, 2007). 
ought to be respected as a participant rather than merely treated as an object. ${ }^{, 42}$ The defendant should be given a central, and ideally an active, role in the trial. ${ }^{43}$ Duff et al. 's normative arguments highlight the importance of facilitating meaningful communication. They recognise that, if we want to protect citizens against the state's potentially oppressive penal power, we should allow, and assist, them to respond to accusations that the state brings against them. ${ }^{44}$ It should be added that the state's oppressive penal power can be inflicted upon defendants not only through formal sanctions post-conviction, but also during the criminal process itself, through assaults on dignity and personhood resulting from, for example, the routine silencing of the defendant. ${ }^{45}$ The silencing of defendants should also be avoided because it denies a voice to, and further disempowers, the disadvantaged groups who tend to be prosecuted, namely the poor and undereducated. As a result, the process that generates our justice system proceeds without these voices, thus reinforcing 'the social and psychological gaps between defendants and those who adjudicate them, ${ }^{46}$

Duff et al. take their communicative conception of the trial further by suggesting that the function of the trial is to call the defendant to account and to communicate with the defendant to get them to see and accept what they have done wrong. Thus, the defendant is called to answer an allegation of wrongdoing and to account for that wrongdoing, if proved. If the defendant does not exercise their right to be heard, the positive purpose of the trial is frustrated ${ }^{47}$ Conversely, it is submitted that the proper purpose of the trial is to call the state to account for the accusations made against the defendant and its request for condemnation and punishment of the defendant. ${ }^{48}$ Within this latter conception of

\footnotetext{
42 Ibid, p 153.

43 A Duff, L Farmer, S Marshall and V Tadros (eds) The Trial on Trial 2: Judgment and Calling to Account (Oxford: Hart Publishing, 2006) p 3.

44 Duff et al, above n 41, p 101.

45 On the court process and practices as a means of inflicting epistemic violence, see E Brissette 'Bad subjects: epistemic violence at arraignment' (2018) Theoretical Criminology, published online, available at https://doi.org/10.1177/1362480618799743 (last accessed 17 May 2020).

46 A Natapoff 'Speechless: the silencing of criminal defendants' (2005) 80 New York University Law Review 1449,1452 . See below for further discussion on the implications of the socio-economic disparities within the criminal justice system.

${ }^{47}$ Duff et al, above n 41, p 102.

48 See Ho, above n 37; A Owusu-Bempah Defendant Participation in the Criminal Process (Abingdon: Routledge, 2017) ch 4.
} 
the trial, the right to participate is fundamental, but does not need to be exercised, at least not in an active way.

Given that the defendant has the right to be presumed innocent and the burden of proof ordinarily rests on the prosecution, ${ }^{49}$ the criminal trial provides a forum to put the prosecution to proof. ${ }^{50}$ In other words, the state must account for (and justify) the accusations made against the defendant. The state is accountable to both the defendant and to the wider public, given that members of the public are subject to state laws, and have an interest in the state acting within its powers. ${ }^{51}$ While attempt should be made to engage the defendant in a dialogue, it is ultimately for the state, through its prosecutorial agencies, to establish guilt. At a minimum, then, engaging the defendant in a dialogue may amount to putting the case to the defendant in a way which they can understand, and providing an opportunity for them to respond. The defendant need not respond and, if the jury is not satisfied that guilt has been proven beyond a reasonable doubt, the defendant should be acquitted. Where the defendant does respond, either personally or through instructions provided to their legal representative, the exercise of participatory rights furthers the objective of calling the state to account; participatory rights provide a means for the defendant to challenge the prosecution case by actively disputing it or by putting forward their own version of events which cast doubt on the prosecution case. In order for the defendant to challenge the prosecution case, or at least understand how and why the prosecution has or has not met its burden of proof, the defendant must be able to follow, understand, and (if they choose) actively contribute to the proceedings. In other words, the defendant must be in a position to meaningfully participate.

The above analysis contends that, regardless of whether participatory rights are exercised by the defendant, they convey respect for the defendant's status as the autonomous subject of the proceedings, and they provide a mechanism for calling the state to account. However, some benefits of participatory rights are attained only when the rights are exercised. For example, defendant participation can increase the perceived legitimacy of the process and the outcome; defendants, as well as the wider

\footnotetext{
49 ECHR, Article 6(2); Woolmington v DPP [1935] AC 462 (HL).

${ }^{50}$ See J Langbein The Origins of the Adversary Criminal Trial (Oxford: Oxford University Press, 2003).

${ }^{51}$ Owusu-Bempah, above n 48, p 9.
} 
community, may be more willing to accept verdicts if the defendant participates. ${ }^{52}$ Moreover, defendant participation can assist in achieving a factually accurate verdict. Where the defendant challenges the case against them through active participation, weaknesses or errors in the prosecution case may be exposed. At the same time, the defendant's participation can assist the state in building and presenting a case, by, for example, providing information that could be used against the defendant. Participation can also further the state's ever-growing quest for an efficient criminal justice system. ${ }^{53}$ Active and cooperative defendants can prevent delay by ensuring early identification of the issues in the case, as required by the Criminal Procedure Rules. ${ }^{54}$ In court, the defendant is likely to be the most efficient witness, able to answer questions which go directly to the facts in issue, while instructions provided to counsel can ensure that questioning of witnesses is confined to the relevant issues.

The potential benefits of the defendant's active participation should not overshadow the fact that it is an exercise of autonomy, and, therefore, should not be compelled. The right to be presumed innocent applies regardless of the role the defendant takes at trial. Moreover, the full benefits of the defendant's participation are most likely to be acquired if it is voluntary. Obligatory participation may, for example, increase the risk of wrongful conviction, as explained below. Also, the perception of legitimacy may depend not only on the fact of participation, but on the quality of the interaction between the state and the defendant. ${ }^{55}$ It is, therefore, important to recognise that the rights to participate exist alongside rights not to participate, notably the privilege against self-incrimination and the right to silence, both of which are implied Article 6 rights. ${ }^{56}$ The participatory rights and the rights not to participate are not in conflict. If one considers that the right to participate provides a choice, rather than an obligation or expectation, then both can easily be accommodated. As Ho puts it, 'It is in recognition

\footnotetext{
$52 \mathrm{~J}$ Jackson and S Summers The Internationalisation of Criminal Evidence: Beyond the Common Law and Civil Law Traditions (Cambridge: Cambridge University Press, 2012) pp 24-25. See also T Tyler Why People Obey the Law (New Haven: Yale University Press, 1990).

${ }^{53}$ See, for example, Sir Brian Leveson Review of Efficiency in Criminal Proceedings (Judiciary of England and Wales, 2015). See also CrimPR 1.1(2)(e), under which the overriding objective of dealing with cases justly includes dealing with cases efficiently and expeditiously.

${ }^{54}$ CrimPR 3.2(2)(a).

${ }^{55}$ Ho, above $\mathrm{n} 37, \mathrm{p} 90$.

${ }^{56}$ Murray v UK (1996) 22 EHRR 29.
} 
of the person's autonomy that we do not force him or her to participate at the trial and, at the same time, give that person the cherished right to do so. ${ }^{57}$

It has been submitted that the rationales for participatory rights should be viewed in terms of respect for the defendant's position as the autonomous subject of the proceedings and as a mechanism for calling the state to account. However, given that the exercise of participatory rights can be of instrumental value to the state, a number of participatory requirements have emerged, with the defendant being penalised for non-cooperation, thus undermining the defendant's rights not to participate. ${ }^{58}$ For example, a failure to answer police questions or give evidence in court can, under certain circumstances, give rise to an adverse inference, allowing the court or jury to treat nonparticipation as evidence of guilt. ${ }^{59}$ Likewise, adverse inferences can be drawn from a failure to comply with requirements to disclose the details of one's defence before trial, and to do so in a manner that is timely and consistent with the defence presented in court. ${ }^{60}$

Requiring participation, as opposed to facilitating it, demonstrates complete disregard for the defendant's autonomy and could put defendants at risk of wrongful conviction. Coerced participation may result in the production of falsely incriminating information, or a lack of participation may be wrongly attributed to guilt. ${ }^{61}$ Nonetheless, a purpose of the state requiring participation seems to be to increase the prospect of a conviction; either the defendant will provide information which may assist the prosecution, or the imposition of a penalty for non-cooperation will help to secure a conviction. ${ }^{62}$ Thus, while there are multiple and, at times, conflicting benefits of defendant participation, in practice, it seems to be sought and valued primarily on the state's terms, as a means of achieving speedy outcomes

\footnotetext{
${ }^{57}$ Ho, above n 37, p 105.

58 See Owusu-Bempah, above n 48.

59 Criminal Justice and Public Order Act 1994, ss 34-39.

60 Criminal Procedure and Investigations Act 1996, ss 5 and 11.

61 It was for these reasons that the Royal Commission on Criminal Justice advised against allowing adverse inferences to be drawn from silence. See Royal Commission on Criminal Justice Report, Cm 2263, 1993 , ch 4.

62 For example, the law allowing adverse inferences to be drawn from silence is intended to prevent defendants from evading conviction by hiding behind silence. In $R v$ Hoare [2004] EWCA Crim 784, Auld LJ explained that 'the section 34 inference is concerned with flushing out innocence at an early stage or supporting other evidence of guilt at a later stage' (at [54]). For a review of the debates that preceded the enactment of ss 34-39 of the Criminal Justice and Public Order Act 1994, see M Zander 'Abolition of the right to silence, 1972-1994' in D Morgan and GM Stephenson (eds) Suspicion and Silence: The Right to Silence in Criminal Investigations (London: Blackstone Press, 1994).
} 
(ideally, from the state's perspective, a conviction). If this is how the defendant's participation is valued, this could explain why there continue to be so many barriers to meaningful participation and communication between the defendant and the court. When the focus is on efficient fact-finding, rather than respecting autonomy and holding the state to account (or even the legitimacy of outcomes), there is less incentive to facilitate meaningful participation, and more incentive to treat the defendant as an object and evidential resource.

\section{BARRIERS TO MEANINGFUL PARTICIPATION}

The position taken in this article is that defendants should be treated as the subject of court proceedings. However, defendants often appear to be the least important character in court. In their study of the publics' experience of the Crown Court, Jacobson et al. describe defendants as 'ever-present extras' and 'mere observers as their fate is decided'. ${ }^{63}$ Defendants tend not to be engaged in court processes or procedures, and, when giving evidence, may struggle to understand or respond to questions. There are numerous barriers to meaningful participation and communication in criminal proceedings which both enable and result in the defendant's treatment as an object rather than the subject of the proceedings. It is not possible to address all of the barriers within the scope of this article. However, to appreciate the extent to which the normative rationales of participatory rights have been overlooked, often in pursuance of efficient fact-finding, and to determine how best to facilitate meaningful participation, it is necessary to highlight some of the most significant barriers.

\section{a. Formality and professionalisation of the criminal process}

A legal culture which discourages the defendant's active participation developed over a long period of time, largely as a result of the emergence of adversarialism in the eighteenth century. ${ }^{64}$ In particular, an

\footnotetext{
63 Jacobson et al, above n 6, pp 83 and 202. See also J Jacobson, G Hunter and A Kirby 'Supporting the effective participation of defendants in court proceedings' (Birkbeck, University of London, 2014); A Kirby, J Jacobson and G Hunter 'Effective participation or passive acceptance: how can defendants participate more effectively in the court process?' Howard League What is Justice? Working Papers (The Howard League for Penal Reform, 2014).

${ }^{64}$ See Langbein, above n 50.
} 
increase in the use of lawyers meant that defendants did not have to speak for themselves in order to avoid conviction. ${ }^{65}$ While many fair trial rights, including the presumption of innocence, are better safeguarded under adversarialism than in the pre-adversarial system, the professionalisation of the criminal trial distanced the defendant from the court process. ${ }^{66}$ When lawyers take responsibility for the conduct and presentation of the case, the role of the defendant can be 'effectively confined to that of a spectator ${ }^{9}{ }^{67}$ resulting in defendants feeling incidental to criminal proceedings ${ }^{68}$ In his study of Wood Green Crown Court, published in 1993, Rock found that the defendant 'would often be discussed as if he were not present. ${ }^{69}$ Since then, courts have become required to take reasonable steps to facilitate the participation of defendants, as stated in the Criminal Procedure Rules, discussed below, ${ }^{70}$ and many lawyers seek to engage the defendant. At the same time, however, the focus on managerialism within the Criminal Procedure Rules is likely to have exacerbated the exclusion of the defendant from the criminal process. Judges have extensive case management duties under Part 3 of the Rules. They must, with the assistance of the lawyers, actively manage the case in furtherance of the overriding objective of dealing with cases justly. ${ }^{71}$ Dealing with cases justly includes 'dealing with cases efficiently and expeditiously'. ${ }^{72}$ In pursuit of this goal, judges are tasked with, inter alia, encouraging agreement between parties and ensuring that trials begin promptly, are as narrowly focussed as possible, and do not last longer than necessary. ${ }^{73}$ By prioritising efficiency and expediency, the defendant, who has little say in administrative matters, becomes further marginalised, while legal professionals dictate the progress of the case.

\footnotetext{
${ }^{65}$ See JM Beattie Crime and the Courts in England 1660-1800 (Oxford: Clarendon Press, 1986); JM Beattie 'Scales of justice: defense counsel and the English criminal trial in the eighteenth and nineteenth centuries' (1991) 9 Law and History Review 221.

${ }^{66}$ On the 'differentiation' between barristers and their clients, see L Mulcahy Legal Architecture: Justice, Due Process and the Place of Law (Abingdon: Routledge, 2011) pp 60-64. On the changing role of defendants, see also, R Gimson 'The mutable defendant: from penitent to rights-bearing and beyond' (2020) 40 LS 113.

${ }^{67} \mathrm{~W}$ Wohlers 'The role of counsel in criminal proceedings: differences between common law and civil law systems' in J Jackson and S Summers (eds) Obstacles to Fairness in Criminal Proceedings: Individual Rights and Institutional Forms (Oxford: Hart Publishing, 2018) p 135.

${ }^{68}$ Jacobson et al, above $\mathrm{n} 6, \mathrm{p} 97$.

${ }^{69}$ P Rock The Social World of an English Crown Court (Oxford: Oxford University Press, 1993) p 240.

${ }^{70}$ CrimPR 3.9(3).

${ }^{71}$ CrimPR 3.2 and 3.3.

${ }^{72}$ CrimPR 1.1(2)(e).

73 J McEwan 'From adversarialism to managerialism: criminal justice in transition' (2011) 31 LS 519, 527.
} 
The professionalisation of the trial is also evident in the case law on the right to effective participation. As noted above, the courts have found it possible (and even sufficient) for the right to be exercised by proxy. Thus, Article 6 does not always require that the defendant is able to hear and follow proceedings, as long as their legal representatives can. ${ }^{74}$ This approach to effective participation is at odds with the rationales for participatory rights advocated above. The right to follow proceedings should be a personal one which can be exercised by the defendant. ${ }^{75}$ If the defendant is to be treated as the subject of the proceedings, as someone who can challenge the case against them and understand the basis for conviction or acquittal, they must be able to hear, understand and engage with what is said in court. This is not to suggest that every defendant must understand every point of law or evidential detail that is discussed or presented in court. Given the complex nature of criminal and procedural law, it is unobjectionable to expect counsel to explain some matters to the defendant. ${ }^{76}$ However, this must be kept within limits. To put the onus on the defendant's lawyer to explain to the defendant everything that has been done or said in court, after it has been done or said, further excludes the defendant from the proceedings and undermines their role as a participant. ${ }^{77}$ It is also important to acknowledge that a small minority of defendants in the Crown Court are not legally represented. ${ }^{78}$ Unrepresented defendants often have little prospect of comprehending all of the laws and rules on procedure, or presenting their case coherently, ${ }^{79}$ yet are deemed able to participate effectively. Consequently, in practice, there may be no real expectation that defendants are personally able to follow court proceedings, and defendants may

\footnotetext{
${ }^{74}$ See Stanford $v U K$, above n 21; $R v$ Hamberger, above $\mathrm{n} 33$. However, in order to effectively participate by proxy, the defendant must be able to instruct and adequately communicate with their lawyer outside of the courtroom. See $T v \mathrm{UK}$, above n 21, at [90].

${ }^{75}$ S Trechsel Human Rights in Criminal Proceedings (Oxford: Oxford University Press, 2005) pp 253, 335.

${ }^{76}$ The right to effective participation does not require that the defendant should understand or be capable of understanding every point of law or evidential detail, given the right to legal representation. See $S C v U K$, above n 21, at [29].

77 Owusu-Bempah, above n 28, pp 332-333.

${ }^{78}$ In 2017, 5\% of defendants in the Crown Court were unrepresented at the first hearing. Ministry of Justice Criminal Court Statistics (Quarterly): January to March 2018, p 17, available at https://assets.publishing.service.gov.uk/government/uploads/system/uploads/attachment data/file/720026/ccsqbulletin-jan-mar-2018.pdf (last accessed 17 May 2020). A rise in the number of unrepresented defendants in recent years has been attributed to cuts to legal aid. See O Bowcott 'Jump in Unrepresented Defendants as Legal Aid Cuts Continue to Bite' The Guardian (London, 24 November 2019) available at https://www.theguardian.com/law/2019/nov/24/legal-aid-cuts-prompt-rise-in-unrepresented-defendants (last accessed 17 May 2020).

${ }^{79}$ See Transform Justice Justice Denied? The Experience of Unrepresented Defendants in the Criminal Courts (Transform Justice, 2016) available at http://www.transformjustice.org.uk/wp-content/uploads/2016/04/TJAPRIL Singles.pdf (last accessed 17 May 2020).
} 
resign themselves to being unable to fully follow what is happening. To rectify this, a broader approach to what constitutes 'effective participation' must be adopted ${ }^{80}$ In particular, understanding and engagement by legal representatives should not be treated as a substitute for that of the defendant.

Related to professionalisation is the formality of trial proceedings. This can cause defendants to feel uncomfortable, intimidated and alienated, particularly in the Crown Court where judges and counsel wear wigs and gowns. In their study, Jacobson et al. note 'a lack of understanding of both the court procedure and the language used by legal professionals, which together generate the sense of a voice unheard, or lost, in the complex mechanisms of the courtroom, ${ }^{81}$ Defendants seemed to accept that courts are a world in themselves on which outsiders have little impact. ${ }^{82}$ One of the defendants interviewed for the study summed up the situation as follows: 'Well, it's posh innit? The courts are posh. It's all posh to me, everyone in wigs; everyone talks in this funky language. ${ }^{83}$ The situation is worse for children ${ }^{84}$ and defendants with learning disabilities or communication difficulties. ${ }^{85}$ Such individuals have been recorded as finding the criminal justice system 'scary', being confused and finding it hard to understand what is happening in court, pretending to understand, and being eager for the proceedings to come to an end. ${ }^{86}$ These defendants might be classed as 'vulnerable' and entitled to special measures or trial adjustments, as explained below. However, even where special measures and trial adjustments are available, the assistance may not fully alleviate the difficulties faced by defendants.

For some defendants, experiences of exclusion may be worsened by an inability to relate to those who are running their case, due to variations in racial and socio-economic backgrounds. These variations are demonstrated by the available statistics. For example, in 2016, 21 percent of those proceeded against in court for indictable offences were from a Black, Asian, Mixed, Chinese or 'Other'

\footnotetext{
${ }^{80}$ See Owusu-Bempah, above n 28.

${ }^{81}$ Kirby et al, above n 63, p 6. These findings echo those of earlier studies, such as Rock, above n 69.

82 Jacobson et al, above n 6, p 197.

83 Ibid, p 101.

${ }^{84}$ See, for example, Lord Carlile Independent Parliamentarians' Inquiry into the Operation and Effectiveness of the Youth Court (Ministry of Justice, 2014); A Wigzel, A Kirby and J Jacobson The Youth Proceedings Advocacy Review: Final Report (Institute for Criminal Policy Research, 2015).

${ }^{85}$ See, for example, J Jacobson and J Talbot Vulnerable Defendants in the Criminal Courts: A Review of Provision for Adults and Children (Prison Reform Trust, 2009).

86 See J Talbot, W Clegg and A Fletcher 'Vulnerable voices?' in P Cooper and L Hunting (eds) Addressing Vulnerability in Justice Systems (London: Wildly, 2016).
} 
ethnic background, ${ }^{87}$ whereas just six percent of court judges were categorised as being from a Black, Asian or Minority Ethnic background. ${ }^{88}$ Breaking this down further, in 2016, 11 percent of those proceeded against for indictable offences were black, ${ }^{89}$ whereas, in 2018, only one percent of court judges ${ }^{90}$ and 2.8 percent of barristers were black. ${ }^{91}$ This can be compared to approximately three percent of the general population of England and Wales. ${ }^{92}$ In terms of education, a disproportionate number of barristers attended a UK independent school in comparison to the general population. ${ }^{93}$ While the number of defendants who attended independent schools is unknown, it is likely to be below the average for the wider population. ${ }^{94}$ Research shows that convicted offenders, particularly young offenders, tend to be under-educated, ${ }^{95}$ and levels of learning disabilities are disproportionately high among defendants. ${ }^{96}$

As well as heightening feelings of alienation and discomfort which can inhibit and discourage participation, disparities in racial and socio-economic background can result in anger and cynicism.

\footnotetext{
${ }^{87}$ Ministry of Justice Statistics on Race and the Criminal Justice System 2016 (Ministry of Justice, 2017) p 44, available https://assets.publishing.service.gov.uk/government/uploads/system/uploads/attachment data/file/669094/statist ics on race and the criminal justice system 2016 v2.pdf (last accessed 17 May 2020).

88 Judicial Office Judicial Diversity Statistics 2016 (Judicial Office, 2016) p 8, available at https://www.judiciary.uk/wp-content/uploads/2016/07/judicial-diversity-statistics-2december.pdf (last accessed 17 May 2020). The figure rose to 7\% in 2018. See Judicial Office Judicial Diversity Statistics 2018 (Judicial Office, 2018) p 5, available at https://www.judiciary.uk/wp-content/uploads/2018/07/judicial-diversity-statistics2018-1.pdf (last accessed 17 May 2020).

${ }^{89}$ Ministry of Justice, above $\mathrm{n} 87, \mathrm{p} 44$.

90 Judicial Office Judicial Diversity Statistics 2018 (Judicial Office, 2018) p 5. The judicial diversity statistics for 2016 do not specify the proportion of black judges. Given that the proportion of Black, Asian or Minority Ethnic judges has increased slightly since 2016, it is unlikely that there were more black judges in 2016 than in 2018.

91 Bar Standards Board Diversity at the Bar 2018 (Bar Standards Board, 2019) p 12, available at https://www.barstandardsboard.org.uk/media/1975681/diversity at the bar 2018.pdf (last accessed 17 May 2020). The overall percentage of Black, Asian and Minority Ethnic barristers at the Bar in December 2018 was $13 \%$.

92 Office for National Statistics 2011 Census: General Report for England and Wales, available at https://www.ons.gov.uk/census/2011 census/howourcensusworks/howdidwedoin2011/2011censusgeneralreport (last accessed 17 May 2020).

${ }^{93}$ The Bar Standards Board suggests that the figure is $15.5 \%$, taking account of a high non-response rate. See Bar Standards Board, above n 91, p 19.

94 The Independent Schools Council suggests that over 7\% of school children in England attend an independent school, available at https://www.isc.co.uk/research/ (last accessed 17 May 2020).

95 See, for example, HM Government Reducing Reoffending through Skills and Employment, Cm 6702, 2005; J Talbot Seen and Heard: Supporting Vulnerable Children in the Youth Justice System (Prison Reform Trust, 2010). ${ }^{96}$ Research indicates that between $20 \%$ and $30 \%$ of offenders have learning difficulties or learning disabilities that interfere with their ability to cope within the criminal justice system. See N Loucks Prisoners with Learning Difficulties and Learning Disabilities - Review of Prevalence and Associated Needs (Prison Reform Trust, 2007). Communication difficulties are most prevalent amongst children, with over $60 \%$ of children who offend having communication difficulties. See Talbot, above $\mathrm{n} 5$.
} 
Some defendants perceive decisions and outcomes as being influenced by bias or discrimination based on personal circumstances, such as class and ethnicity. ${ }^{97}$ Perceptions of bias may not be misplaced, as statistics show that people from ethnic minority backgrounds, and black people in particular, are disproportionately represented throughout the criminal process. ${ }^{98}$ One possible (or partial) way to facilitate greater and more meaningful defendant participation is to create a more diverse and representative legal profession, ${ }^{99}$ as well as addressing the causes of the overrepresentation of socially disadvantaged individuals and individuals from ethnic minority groups as defendants. However, while better representation may reduce the discomfort or exclusion of some defendants, it is an insufficient solution.

For decades, researchers have noted an 'us and them' division between legal professionals and lay court users. ${ }^{100}$ The divide stems largely from the factors outlined above: formality; language; background; and, also, camaraderie between legal professionals. However, the divide is not only a consequence of procedural tradition or the complex nature of court proceedings. It can also be viewed as a way of protecting the integrity of the legal process and sustaining the courts' aura of authority. ${ }^{101}$ Additionally, while many lawyers make great effort to engage with lay participants, for some, the division might be thought to reinforce the perception of superiority of legal professionals and their

\footnotetext{
97 Jacobson et al, above n 6, pp 182-184. See also R Hood, S Shute and F Seemungal Ethnic Minorities in the Criminal Courts: Perceptions of Fairness and Equality of Treatment (Department of Constitutional Affairs, 2003); K Irwin-Rogers and M Shuter Fairness in the Criminal Justice System: What's Race got to do with it? (Catch 22, 2017) available at https://www.catch-22.org.uk/wp-content/uploads/2017/04/Fairness-in-the-criminaljustice-system-full-report-3.pdf?utm source=download\&utm medium=google form\&utm campaign=lammy (last accessed 17 May 2020); P Bowen Building Trust: How our Courts can Improve the Criminal Court Experience for Black, Asian, and Minority Ethnic Defendants (Centre for Justice Innovation, 2017) available at http://justiceinnovation.org/wp-content/uploads/2017/03/Building-Trust.pdf (last accessed 17 May 2020).

98 Ministry of Justice Black, Asian and Minority Ethnic Disproportionality in the Criminal Justice System in England and Wales (Ministry of Justice, 2016); Ministry of Justice Statistics on Race and the Criminal Justice System 2016 (Ministry of Justice, 2017). See also D Lammy The Lammy Review (Ministry of Justice, 2017) available https://assets.publishing.service.gov.uk/government/uploads/system/uploads/attachment data/file/643001/lamm y-review-final-report.pdf (last accessed 17 May 2020).

${ }^{99}$ For example, David Lammy has recommended greater diversity among judges and magistrates. See Lammy, above $\mathrm{n} 98$.

${ }^{100}$ See, for example, P Carlen Magistrates' Justice (London: Martin Robertson, 1976); Rock, above n 69; N Fielding Courting Violence: Offences Against the Person Cases in Court (Oxford: Oxford University Press, 2006); Jacobson et al, above $\mathrm{n} 6$.

101 Jacobson et al, above n 6, pp 96 and 201.
} 
ability to 'manage and manipulate' proceedings through, for example, inaccessible language. ${ }^{102}$ This may be lost if defendants (and other lay court users) were fully able to engage with the process. ${ }^{103}$ Yet, the present situation, within which many defendants struggle to understand basic concepts and processes, cannot be justified on the basis that it maintains the superiority of legal professionals over lay court users. Nor is a strong division between legal professionals and lay court users necessary to maintain order or the courts' authority. Arguably, those who are able to fully understand and participate in proceedings are also best able to appreciate the seriousness of the proceedings and what is at stake.

To prevent the 'othering' of defendants, greater recognition and appreciation of the rationales for participatory rights is required. Defendants should be at the centre of the criminal process. They must be seen and treated as the autonomous subject of the proceedings, as being worthy of engagement in a dialogue, and their participation viewed as a mechanism for calling the state to account. One way to better facilitate this could be through a change to the relationship between the defendant and their lawyer. Wohlers has advocated a system of 'hybrid representation', whereby the defendant effectively acts as co-counsel. Defence counsel assists the defendant in conducting and presenting their case, rather than assuming control over the case. ${ }^{104}$ This would allow the defendant to determine the direction and leadership of the defence, while providing the opportunity to engage directly and actively in the proceedings. However, it would also represent a substantial change in approach, and its success would depend on the defendant's ability to understand and engage in the process which, at present, is often lacking. It may, therefore, be more useful to first focus on creating a general change in 'court culture', 105 to enable defendants to better engage with the court.

Several commentators have advocated a procedural justice approach to criminal proceedings, ${ }^{106}$ whereby fair and respectful treatment and neutral decision-making can increase the perceived

\footnotetext{
102 See Fielding, above n 100, p109 and ch 5. See also Rock, above n 69, pp 61-62. On the courts as a mechanism for social control, see Carlen, above n 100.

103 Jacobson et al, above n 6, p 98.

104 See Wohlers, above n 67, ch 7. See also J Colquitt 'Hybrid representation: standing the two-sided coin on its edge' (2003) 38 Wake Forest Law Review 55.

105 A Kirby 'Effectively engaging victims, witnesses and defendants in the criminal courts: a question of "court culture"?’ [2017] Crim LR 949.

106 See, for example, E Gold LaGratta and P Bowen To be Fair: Procedural Fairness in Courts (Criminal Justice Alliance, 2014) available at http://criminaljusticealliance.org/wp-content/uploads/2015/02/TobeFair.pdf (last
} 
legitimacy of the system, as well as foster meaningful engagement and improve understanding. ${ }^{107}$ Such an approach is consistent with the normative rationales for participatory rights, as it promotes 'doing justice' to the accused. In practical terms, procedural justice requires that defendants are treated with courtesy and respect, that they are kept informed and provided with a clear explanation of what is happening and why, and that they have an opportunity to be heard and are taken seriously when they choose to speak. ${ }^{108}$ Since formal and antiquated legal language has been cited by many defendants as a barrier to understanding, procedural justice may necessitate the adoption of clear and simple language at all times during court proceedings. This could benefit all lay court users, including those in the public gallery. To this end, the civil liberties organisation, JUSTICE, has recommended that 'there be a judiciary-led consultation with the profession into modes of address, and commonly misunderstood terminology, and whether they continue to serve a useful purpose when set against any alienating impact they may have. ${ }^{109}$ Many defendants could also benefit from being provided with a glossary of key legal terms and answers to frequently asked questions about the court process. It has also been suggested that simple gestures can indicate to defendants that they are being treated with respect. These gestures include: legal professionals introducing themselves and making eye contact; ${ }^{110}$ judges asking defendants what questions they have; ${ }^{111}$ and speaking to defendants in a non-authoritarian manner. ${ }^{12}$ If we are to take participatory rights seriously, criminal proceedings must be transparent and accessible,

accessed 17 May 2020); Bowen, above n 97, pp 18-20; J Thomas, C Ely and B Estep A Fairer Way: Procedural Fairness for Young Adults at Court (Centre for Justice Innovation, 2018) available at https://justiceinnovation.org/publications/fairer-way-procedural-fairness-young-adults-court (last accessed 17 May 2020).

107 See, for example, Tyler, above n 52; T Tyler 'Procedural justice, legitimacy, and the effective rule of law' (2003) 30 Crime and Justice 283; T Tyler 'Procedural justice and the courts' (2007) 44 Court Review 26; K Kwokyin Cheng 'Legitimacy in a postcolonial legal system: public perception of procedural justice and moral alignment toward the courts in Hong Kong' (2018) 43 Law and Social Inquiry 212.

108 Tyler identified four key procedural justice principles: voice, neutrality, respect and trust. See T Tyler 'Procedural justice and the courts' (2007) 44 Court Review 26, 30-31.

109 Justice Understanding Courts (Justice, 2019) p 67, available at https://justice.org.uk/wpcontent/uploads/2019/01/Understanding-Courts.pdf (last accessed 17 May 2020). See also, The Equal Treatment Bench Book (Judicial College, 2018) 4.

110 Bowen, above n 97, p 18.

111 Gold LaGratta and Bowen, above n 106, p 6.

112 See also Justice, above n 109, which makes a number of practical recommendations aimed at facilitating participation and improving lay people's understanding of the court process. 
with a focus on the 'promotion of respectful, considerate and empathetic interactions'. ${ }^{113}$ Further suggestions for facilitating defendant participation are considered below, in relation to other significant barriers to participation.

\section{b. The dock}

The architecture and design of many court buildings and courtrooms make them intimidating places for those who are unfamiliar with them. ${ }^{114}$ As with the factors set out above, this works to separate the defendant from the legal professionals and can exacerbate feelings of exclusion, alienation and an inability to take part in proceedings. However, the biggest barrier to participation, in terms of the court environment, is arguably the defendant's position in the dock. ${ }^{115}$ In the Crown Court, the dock is situated at the back of the courtroom and is usually a 'secure dock'. Secure docks extend from floor to ceiling and are glass-fronted. Mulcahy observes that the defendant in a secure dock is effectively placed in a separate room within the courtroom. ${ }^{116}$ This does little to signal that the defendant is central to the trial. ${ }^{117}$ Moreover, the courtroom is typically designed such that attention is directed towards the lawyers in the centre of the courtroom, who face the judge and have their backs turned to the defendant. While the positions reserved for lawyers for the defence and prosecution are equivalent, the position reserved for defendants is comparatively marginal and inferior. ${ }^{118}$

\footnotetext{
${ }^{113}$ Kirby, above $\mathrm{n} 105, \mathrm{p}$ 968. In an adversarial trial, the extent to which the prosecution can be expected to treat the defendant with empathy may be limited, particularly if the prosecution case is that the defendant is lying. Nonetheless, the prosecution can approach and engage the defendant in a respectful manner.

114 On the significance of court architecture and design, see generally Mulcahy, above n 66; L Mulcahy and E Rowden The Democratic Courthouse: A Modern History of Design, Due Process and Dignity (Abingdon: Routledge, 2020). See also Rock, above n 69, ch 6.

115 While it is routine for defendants to sit in the dock, there is an exception for children and other vulnerable defendants. In accordance with the Criminal Practice Directions, 'a vulnerable defendant, especially if he is young, should normally, if he wishes, be free to sit with members of his family or others in a like relationship, and with some other suitable supporting adult such as a social worker, and in a place which permits easy, informal communication with his legal representatives.' CPD 3G.8. However, this exception is not automatic and placement of young defendants in the dock will not necessarily render a trial unfair. See $R v M c$ Gill, Hewitt and Hewitt [2017] EWCA Crim 1228.

${ }^{116}$ L Mulcahy 'Putting the defendant in their place: why do we still use the dock in criminal proceedings?' (2013)

53 British Journal of Criminology 1139, 1144.

117 Ibid, p 1143.

118 J Miller 'A rights-based argument against the dock' [2011] Crim LR 216, 220.
} 
By marginalising the defendant, use of the dock prevents meaningful participation in several ways. The physical separation of the defendant from their legal representatives means that there is little opportunity for the defendant to provide instructions, alert their counsel to inaccuracies during a witness's testimony, or to suggest questions for cross-examination. According to Stone and Blackstock, consultation with counsel 'is subject to gaining their attention by banging, waving and other demeaning methods; consultation is done within hearing of other parties, the dock officer, anyone else in the dock, and if it is particularly difficult to communicate through the glass, everyone else in the courtroom.' 119 Thus, confinement to the dock prohibits free and uninterrupted consultation and suggestion during the trial. ${ }^{120}$ It can also be difficult for defendants to hear proceedings from the dock, ${ }^{121}$ meaning that even those who are capable of understanding and engaging in the court process cannot properly follow the proceedings. As Mulcahy notes, 'rather than facilitating their participation in the trial, the use of the dock appears to signal the expectation that the defendant remains silent and passive'. ${ }^{22}$ However, defendants should not be too silent; if they fail to testify, adverse inferences may be drawn against them. Thus, during the course of the trial, defendant participation is sought by the state, but only when the defendant is called to give evidence. ${ }^{123}$ As well as preventing participation, the dock has been criticised on the basis that it is likely to prejudice the jury against the defendant by making the defendant appear guilty $^{124}$ and increasing the prospect of a conviction. ${ }^{125}$

Use of the dock indicates lack of concern about, or awareness of, the rationales which should underpin participatory rights. Far from being enabled to challenge the prosecution case or engage in a dialogue as the autonomous subject of the proceedings, the defendant in the dock is 'a man apart. He is

\footnotetext{
119 J Stone and J Blackstock 'Violating the right to a fair trial? the secure dock in England and Wales' (2017) Archbold Review 4, 6.

${ }^{120}$ Miller, above $\mathrm{n} 118, \mathrm{p} 221$.

121 Justice In the Dock: Reassessing the Use of the Dock in Criminal Trials (Justice, 2015) p 15, available at https://justice.org.uk/wp-content/uploads/2015/07/JUSTICE-In-the-Dock.pdf (last accessed 17 May 2020).

${ }_{122}$ Mulcahy, above n 116, p 1144.

${ }^{123}$ It is also notable that, while the threat of adverse inferences interferes with the right not to participate, limited access to special measures can prevent the defendant from giving their best evidence. See below.

${ }^{124}$ See, for example, L Rosen 'The dock - should it be abolished?' (1966) 29 MLR 289; Miller, above n 118; Mulcahy, above n 116; Justice, above n 121.

${ }^{125}$ A study using mock jurors in Australia found that jurors are more likely to convict defendants when they are located in a dock, compared to having them sit next to their counsel at the bar table. See M Rossner, D Tait, B McKimmie and R Saare 'The dock on trial: courtroom design and the presumption of innocence' (2017) 44 Journal of Law and Society 317.
} 
the cynosure of all eyes. He is placed, as it were, in a pillory, and must feel he is an object of scorn and derision. ${ }^{126}$ Rosen describes the experience of being in the dock as 'humiliating and degrading'. ${ }^{127}$ Likewise, a report by JUSTICE asserts that 'enclosing a person in a glass box or wooden pen is clearly an objectively humiliating experience and its rationale must be questioned as an affront to the dignity of proceedings. ${ }^{, 128}$ Not only is it an affront to the dignity of the proceedings, but it is an affront to the dignity of the defendant.

Due to its undignified nature, as well as its interference with the right to legal assistance and the presumption of innocence, routine use of the dock is unconstitutional in the United States. ${ }^{129}$ In Europe, the European Court of Human Rights has recognised that holding a defendant in a metal cage is degrading and constitutes an 'affront to human dignity' in breach of Article 3 of the ECHR. ${ }^{130}$ More recently, use of a glass dock has been successfully challenged in the European Court. The Court has held that, while confinement of the defendant in a glass dock does not in and of itself breach Article 3, it may do so if the circumstances of the confinement meet the minimum level of severity required to characterise the treatment as degrading within the meaning of Article $3 .{ }^{131}$ This level of severity was reached in Alekhina v Russia, where the glass dock had been constantly surrounded (and observed) by armed police officers and court ushers, as well as a guard dog. ${ }^{132}$ The Court also found a breach of Article 6 on the grounds that the defendant's position in the dock prevented free and private communication with their lawyers during the trial. ${ }^{133}$ There had been a violation of the right to participate effectively and the right to receive practical and effective legal assistance.

\footnotetext{
126 Rosen, above n 124, p 297.

127 Ibid, p 296.

128 Justice, above n 121, p 24.

129 See Illinois v Allen, 397 US 337 (1970); Young v Callahan, 700 F.2d 32, 36 (1 st Cir 1983); Deck v Missouri, 544 US 622 (2005).

130 See Svinarenko and Slyadnev v Russia App no 32541/08 and 43441/08 (ECHR (GC), 17 July 2014) at [138].

131 See Yaroslav Belousov v Russia App no 2653/13 and 60980/14 (ECHR, 4 October 2016) at [125].

132 Alekhina v Russia (2019) 68 EHRR 14 at [147]-[149]. See also Yaroslav Belousov v Russia, above n 131, where Article 3 was breached due to the fact that 10 defendants had been held in a 'glass cabin' for two months of their high profile trial, with virtually no space between them.

133 Alekhina $v$ Russia, above n 132, at [166]-[172].
} 
Based on the European jurisprudence, the conditions in which most defendants in England and Wales sit in the dock are unlikely to breach Article $3 .{ }^{134}$ However, there is certainly scope to argue that English procedure, whereby defendants in the Crown Court are routinely placed in a secure dock, is incompatible with Article $6 .{ }^{135}$ The European Court has stressed that, while mindful of security issues, 'any measures restricting the defendant's participation in the proceedings or imposing limitations on his or her relations with lawyers should only be imposed in so far as is necessary, and should be proportionate to the risks in a specific case. ${ }^{, 136}$

There is no legal authority requiring routine use of the dock, and experience in other jurisdictions proves that it is unnecessary. In South Africa, Ireland, and Denmark, for example, the dock is either non-existent or rarely used. Likewise, in the United States, a jurisdiction with higher rates of violent crime than England and Wales, the standard practice is for defendants to sit next to their counsel, and some lawyers make a conscious effort to appear at ease with their clients and to demonstrate the defendant's involvement to the jury. ${ }^{137}$ Where defendants pose a real risk of violence or escape, additional security officers can be made available, or concealed restraints can be used. Campaigns in the 1960s and 1970s to limit or abolish the dock in England and Wales received considerable support from key stakeholders, including practitioners and politicians. ${ }^{138}$ More recently, objection to the dock has been voiced by academics, ${ }^{139}$ practitioners, ${ }^{140}$ JUSTICE, ${ }^{141}$ and the Howard League for Penal Reform. ${ }^{142}$ There also seems to be some judicial support for the prospect of abolishing the dock. ${ }^{143} \mathrm{~A}$

\footnotetext{
134 Defendants are accompanied by any co-defendants, a custody officer and sometimes other professionals, such as an interpreter. However, the dock is not typically overcrowded, as it was in Yaroslav Belousov. Nor is the dock guarded by armed officers, as in Alekhina.

135 Stone and Blackstock, above n 119, p 6.

136 Alekhina v Russia, above n 132, at [169].

137 Mulcahy, above n 116, pp 1149-1152.

138 Ibid, p 1144-1149.

139 See, for example, Miller, above n 118; Mulcahy, above n 116; Rossner et al, above n 125; Mulcahy and Rowden, above n 114.

140 See, for example, M Scott 'Get rid of the docks!' (2015) 179 Criminal Law and Justice Weekly 99; J Stone 'Is it now time to abolish the dock in all criminal proceedings in England and Wales?' (2015) Archbold Review 7.

141 Justice, above n 121.

142 L Mulcahy, M Rossner and E Rowden 'What if the dock was abolished in criminal courts?' (Howard League for Penal Reform, 2020) available at https://howardleague.org/wp-content/uploads/2020/01/What-if...-the-dockwas-abolished-1.pdf (last accessed 17 May 2020).

143 O Bowcott 'Senior judge calls for abolition of security cages from courtrooms' The Guardian (London, 3 July 2015) available at https://www.theguardian.com/law/2015/jul/03/senior-judge-abolition-courtroom-dockssecurity-cage (last accessed 17 May 2020).
} 
change to the seating arrangements in the courtroom should, therefore, constitute a relatively uncontroversial move towards taking participatory rights seriously and treating the defendant as the subject, rather than the object, of criminal proceedings.

\section{c. Special measures}

As noted above, it can be particularly difficult for children ${ }^{144}$ and other 'vulnerable ${ }^{145}$ defendants to navigate the formality and professionalisation of the court process. The court is required to take every reasonable step 'to facilitate the participation of any person, including the defendant'. ${ }^{146}$ In accordance with the Criminal Practice Directions, this includes 'enabling a witness or defendant to give their best evidence, and enabling a defendant to comprehend the proceedings and engage fully with his or her defence' ${ }^{147}$ In furtherance of this Direction, special measures and trial adjustments can be put in place to assist those who are deemed to be vulnerable. In fact, while many adult defendants with no notable communication or health issues struggle to participate, it is in relation to vulnerable defendants that the most significant progress has been made to improve participation. ${ }^{148}$ However, for defendants, there are strict eligibility criteria and limited access to certain special measures. Although a full overview of special measures and trial adjustments is beyond the scope of this article, ${ }^{149}$ this section seeks to

\footnotetext{
${ }^{144}$ Young defendants are ordinarily tried in the youth court, where procedures are adapted to take account of age. However, trials for certain serious offences, including murder, take place in the Crown Court. While this article is concerned primarily with contested Crown Court trials, attaining meaningful participation is also an issue in the youth court. See, for example, C Robin-D'Cruz Young People's Voices on Youth Court (Centre for Justice Innovation Briefing Paper, 2020) available at https://justiceinnovation.org/publications/young-peoples-voicesyouth-court (last accessed 17 May 2020).

${ }^{145}$ Note that there is no single or legal definition of what constitutes a 'vulnerable' witness or defendant. Drawing from the eligibility criteria for special measures in ss 16 and 17 of the YJCEA 1999, the Criminal Practice Directions state that: "vvulnerable" includes those under 18 years of age and people with a mental disorder or learning disability; a physical disorder or disability; or who are likely to suffer fear or distress in giving evidence because of their own circumstances or those relating to the case.' The Direction also acknowledges that 'many other people giving evidence in a criminal case, whether as a witness or defendant, may require assistance'. See CPD 3D.1-3D.2.

146 CrimPR 3.9(3)(b).

147 CPD 3D.2.

${ }^{148}$ See, for example, The Advocate's Gateway toolkits, particularly, Toolkit 8: Effective Participation of Young Defendants, available at www.theadvocatesgateway.org/toolkits (last accessed 17 May 2020), as well as the Inns of Court College of Advocacy's training programme, 'Advocacy and the Vulnerable', available at https://www.icca.ac.uk/advocacy-the-vulnerable-crime/ (last accessed 17 May 2020). See also, The Equal Treatment Bench Book (Judicial College, 2018).

${ }^{149}$ See generally, P Cooper and H Norton (eds) Vulnerable People and the Criminal Justice System: A Guide to Law and Practice (Oxford: Oxford University Press, 2017).
} 
demonstrate that the current approach does not go far enough to facilitate the meaningful participation of vulnerable defendants.

Many of the steps which the court can take to assist vulnerable defendants are set out in the Criminal Practice Directions. ${ }^{150}$ They include: adjustments to style and approach to questioning; ${ }^{151}$ shortened sitting times and regular breaks; restricted attendance; removal of wigs and gowns; allowing the defendant to sit outside of the dock; and availability of a supporting adult. For the significant number of defendants who have communication difficulties, ${ }^{152}$ the assistance of an intermediary can be particularly helpful. Yet, it is in relation to the provision of intermediaries that we clearly see the shortcomings in present practice.

Intermediaries are communication specialists who can facilitate witness' understanding of, and communication with, the court. ${ }^{153}$ There is a statutory provision for defendant intermediaries, but it is not in force. ${ }^{154}$ Notably, the legislation only provides for defendant intermediaries to assist with giving evidence, and not to facilitate understanding during other parts of the proceedings. This in itself creates the impression that defendant participation is sought primarily (if not solely) as a means of acquiring evidence. Although the legislative provision is not in force, the court has inherent jurisdiction to appoint an intermediary to assist the defendant throughout criminal proceedings. ${ }^{155}$ While this is indicative of the judicial commitment to supporting vulnerable defendants, the provision of intermediaries at common law is not satisfactory. ${ }^{156}$ Applications for defendant intermediaries have been granted by

\footnotetext{
150 See CPD 3D-3G.

151 On the changing rules and rationale of cross-examination, see Henderson, above n 4; E Henderson 'Theoretically speaking: English judges and advocates discuss the changing theory of cross-examination' [2015] Crim LR 929; E Henderson 'Taking control of cross-examination: judges, advocates and intermediaries discuss judicial management of the cross-examination of vulnerable people' [2016] Crim LR 181.

152 On the prevalence of communication difficulties, learning disabilities and mental health problems among defendants, see, for example, Loucks, above n 96; The Bradley Report: Lord Bradley's Review of People with Mental Health Problems or Learning Disabilities in the Criminal Justice System (Department of Health, 2009); Talbot, above n 95; Talbot, above n 5; Wigzel et al, above n 84; Justice, Mental Health and Fair Trial (Justice, 2017).

153 See generally J Plotnikoff and R Woolfson Intermediaries in the Criminal Justice System: Improving Communication with Vulnerable Witnesses and Defendants (Bristol: Policy Press 2015).

154 YJCEA 1999, ss 33BA and 33BB, inserted by the Coroners and Justice Act 2009, s 104.

155 See, for example, C v Sevenoaks Youth Court [2009] EWHC 3088 (Admin); CPD 3F.11-3F.18.

${ }^{156}$ For a discussion of the shortcomings of intermediaries for defendants, see generally Cooper and Wurtzel, above n 5; D Wurtzel 'Intermediaries for defendants: recent developments' [2017] Crim LR 463. See also Law Commission, above n 5 , ch 2 .
} 
judges on an ad hoc basis, resulting in inconsistency. ${ }^{157}$ Defendants are excluded from the 'Registered Intermediary' scheme, so intermediaries for defendants are not quality-assured in the same way as intermediaries for non-defendant witnesses. ${ }^{158}$ Also, there are significant resource issues, particularly in terms of funding and identifying available intermediaries. Resourcing concerns have resulted in amendments to the Criminal Practice Directions which now explicitly seek to limit the provision of intermediaries for defendants (no such limits have been explicitly placed on the provision of intermediaries for eligible non-defendant witnesses). ${ }^{159}$ In accordance with the Directions, intermediaries should be appointed to assist defendants to give evidence only 'rarely', and appointment for the duration of a trial should be 'extremely rare'. ${ }^{160}$ This position has been supported by the Court of Appeal. ${ }^{161}$ In Rashid, the Court took the view that, in the overwhelming majority of cases, competent legal representation and good trial management is sufficient to assist participation and ensure a fair trial. $^{162}$

Thus, in place of intermediaries, most defendants with communication problems must rely on: adjustment to the language used in court; ${ }^{163}$ 'competent legal representation'; ${ }^{164}$ and, where additional assistance is necessary, 'a support worker or other appropriate companion who can provide that assistance' ${ }^{165}$ Intermediaries are not always required when all that is needed to facilitate understanding is a simple change to the style of questioning or language used in court. However, lawyers, or other 'suitable supporting adults', ${ }^{166}$ should not be regarded as a convenient, resource-neutral substitute for an intermediary. ${ }^{167}$ Lawyers and intermediaries can have significantly different opinions on what kind

\footnotetext{
${ }^{157}$ Law Commission, above n 5, para 1.27 .

${ }^{158}$ See $R$ (on the application of OP) $v$ the Secretary of State for Justice and Others [2014] EWHC 1944 (Admin), where exclusion from the Registered Intermediary scheme was successfully challenged. However, there has yet to be a change in practice.

${ }^{159}$ For a critique of the amendment, see Hoyano and Rafferty, above $\mathrm{n} 5$.

160 CPD 3F.13.

${ }^{161} R v$ Rashid [2017] EWCA Crim 2; $R v$ Biddle [2019] EWCA Crim 86.

$162 R v$ Rashid, above $\mathrm{n} 161$, at [73].

${ }^{163}$ See CPD 3G.10. See also CPD 3F.12, which states: 'The court should adapt the trial process to address a defendant's communication needs ... It will rarely exercise its inherent powers to direct appointment of an intermediary'.

${ }^{164} R v$ Rashid, above n 161, at [73].

165 CPD 3F.12.

166 CPD 3G.8.

${ }^{167}$ Stone, above n 5, p 182.
} 
of adaptations to language or questioning is required to facilitate understanding, with lawyers missing problems that can be identified by intermediaries. ${ }^{168}$ Moreover, an intermediary may be necessary to enable the defendant to communicate with their lawyer outside of the courtroom. Arguably, the legislature and, more recently, the appellate courts have been too quick to prioritise resourcing concerns at the expense of 'enabling a defendant to comprehend the proceedings and engage fully with his or her defence'. This creates the impression that doing justice to the accused is not worth the cost.

There are also shortcomings in respect of the one statutory special measure that is available to defendants: live-link. ${ }^{169}$ Live-link enables the defendant to give their evidence from outside of the courtroom. By removing them from the busy and intimidating courtroom environment, the defendant may be better able to concentrate, thus increasing their ability to understand the questions put to them, respond in a coherent and consistent manner, and engage with the questioner. However, eligibility criteria for live-link is strict. In accordance with section 33A of the YJCEA 1999, live-link is only available to defendants where it is in the interests of justice and, additionally, either: the defendant is under the age of 18 , their ability to participate effectively as a witness is compromised by their level of intellectual ability or social functioning, and the use of live-link would enable them to participate more effectively as a witness; or the defendant is unable to participate effectively as a witness due to a mental disorder or other significant impairment of intelligence and social function, and the use of live-link would enable them to participate more effectively as a witness. ${ }^{170}$

The eligibility criteria for defendants is more restrictive than that for other witnesses. For example, unlike non-defendant witnesses, the legislation does not provide for live-link where a physical disability prevents the defendant from giving evidence in the courtroom. ${ }^{171}$ Nor are defendants eligible for live-link on the grounds of fear or distress about testifying. ${ }^{172}$ The lack of parity is most stark in

168 See K Hanna and E Henderson '"[Expletive], that was confusing, wasn't it?" defence lawyers' and intermediaries' assessment of the language used to question a child witness' (2018) 22 International Journal of Evidence and Proof 412.

169 YJCEA 1999, s 33A. As inserted by s 47 of the Police and Justice Act 2006.

170 YJCEA 1999, ss 33A(2)-(5).

171 See $R$ v Hamberger, above $\mathrm{n} 33$.

172 YJCEA 1999, s 17. 
respect of children, as young non-defendant witnesses are automatically eligible for live-link. ${ }^{173}$ Implicit in the rules that apply to non-defendant witnesses is recognition that the quality of a child's evidence, and their ability to give evidence effectively, may be improved if they are not in the courtroom. It is unclear why this logic does not also apply to young defendants, particularly given that child defendants 'are often amongst the most disadvantaged and the least able to give a good account of themselves'. ${ }^{174}$ The current approach of prioritising special measures for non-defendant witnesses does little to signal that the defendant is the subject and key stakeholder in the proceedings.

The disparity in the availability of special measures for defendants and other witnesses has been the subject of much academic criticism, ${ }^{175}$ not least because it interferes with the principle of equality of arms. ${ }^{176}$ In its report on unfitness to plead, the Law Commission recommended greater provision of special measures for defendants and that the eligibility criteria for live-link be brought into line with that for non-defendant witnesses. ${ }^{177}$ However, changes to eligibility criteria are unlikely to suffice. A small-scale study conducted by Fairclough shows that, even where live-link is available to defendants, the statutory provision is rarely invoked. ${ }^{178}$ Fairclough attributes this to a number of factors, including: lack of awareness of the live-link provision among legal professionals; poor identification of vulnerability by those working within the legal profession; ${ }^{179}$ and, importantly, lack of perceived practical benefit or tactical advantage. According to the legal professionals interviewed by Fairclough, the function of live-link is to keep witnesses out of the courtroom entirely. Since defendants sit in the courtroom up to the point at which they are called to give evidence, it may appear unnecessary to remove them in order to testify. ${ }^{180}$ Moreover, some thought that the defendant's absence from the courtroom

\footnotetext{
173 Ibid, ss 16 and 21.

${ }^{174} R$ (on the application of D) v Camberwell Green Youth Court, above n 19, at [56], per Baroness Hale.

175 See, for example, Fairclough, above n 5.

176 See, for example, L Hoyano 'Striking a balance between the rights of defendants and vulnerable witnesses: will special measures directions contravene guarantees of a fair trial?' [2001] Crim LR 948; Hoyano, above n 5. 177 Law Commission, above n 5, ch 2 and paras 2.93-2.94.

178 S Fairclough “"It doesn't happen... and I've never thought it was necessary for it to happen": barriers to vulnerable defendants giving evidence by live link in Crown Court trials' (2017) 21 International Journal of Evidence and Proof 209.

179 This can result not only from an inability to recognise or uncover specific vulnerabilities, but also from a reluctance to view defendants as being vulnerable, and viewing defendants as undeserving of special measures. See S Fairclough 'Using Hawkins's surround, field, and frames concepts to understand the complexities of special measures decision making in Crown Court trials’ (2018) 45 Journal of Law and Society 457, 472-473.

180 See Fairclough, above n 178, p 219.
} 
could be viewed as suspicious by the jury, or would diminish the impact of the defendant's testimony on the jury. ${ }^{181}$

Examination through live-link (as well as use of other measures and adjustments) is not in the best interest of every eligible defendant, and some vulnerable defendants will be able to give evidence more effectively in the courtroom than from a distance. Nonetheless, the attitudes expressed by some of the participants in Fairclough's study are representative of the 'us and them' mentality in so far as they reveal a lack of awareness of (or concern about) the extent of the difficulties faced by some defendants in court. ${ }^{182}$ Fairclough's analysis also indicates that the defendant's ability to understand and communicate is not viewed as a priority in criminal proceedings. Nor is meaningful defendant participation a priority for the legislature, as evidenced by the fact that, unlike non-defendant witnesses, special measures for defendants were introduced by the government in 'grudging recognition' ${ }^{183}$ of the challenges faced by vulnerable defendants, as a response to findings against the UK in the European Court of Human Rights. ${ }^{184}$

It is worth briefly noting the relevance of special measures in cases where the defendant may not be able to exercise their right to effective participation. Given that special measures were introduced to enable defendants to have a fair trial, it is understandable that the availability of special measures and trial adjustments increases the likelihood of a judge finding that the defendant can participate effectively. ${ }^{185}$ However, the value of special measures in individual cases may be speculative, as evidenced by the fact that experts do not always agree on which adjustments or measures, if any, will enable effective participation. ${ }^{186}$ As noted elsewhere, it is, therefore, concerning that, where assistance

\footnotetext{
181 Ibid, pp 220-223.

182 However, many practitioners are troubled by the disparate treatment and difficulties faced by vulnerable defendants in court. See, for example, J Plotnikoff and R Woolfson Falling Short? A Snapshot of Young Witness Policy and Practice (NSPCC, 2019) ch 5.8.

${ }^{183}$ L Hoyano 'Reforming the adversarial trial for vulnerable witnesses and defendants' [2015] Crim LR 107, 127. ${ }^{184}$ See $T v U K$, above $\mathrm{n} 21 ; S C v U K$, above $\mathrm{n} 21$. On the problems caused by the way in which special measures for defendants have developed, see $\mathrm{S}$ Fairclough 'The consequences of unenthusiastic criminal justice reform: a special measures case study' (2019) Criminology and Criminal Justice, first published online, available at https://doi-org.gate3.library.lse.ac.uk/10.1177/1748895819848804 (last accessed 17 May 2020).

${ }^{185}$ See, for example, $R$ (on the application of $P$ ) $v$ West London Youth Court [2005] EWHC 2583 (Admin); $R v D$ [2013] EWCA Crim 465.

${ }^{186}$ See, for example, O'Donnell $v$ UK App no 16667/10 (ECHR, 7 April 2015); $R v$ Rashid, above $n 161$.
} 
is available, this can overshadow the problems faced by those who would struggle with participating and who do not wish to participate. ${ }^{187}$ Eligibility for special measures should signal that a defendant will have particular difficulty in following proceedings or giving evidence. Yet, the availability of special measures has not only contributed to findings that defendants with severe communication problems can participate effectively, but also that they should actively participate in their trials, and that adverse inferences may be drawn against them if they do not give evidence. ${ }^{188}$ Again, it seems that defendant participation is not sought as a means of giving effect to the proposed rationales for participatory rights. Rather, it is desired in pursuit of the instrumental values of participation that benefit the state, namely efficient fact-finding, with defendants being expected to provide evidence even if they may not be able to do so adequately. This claim is strengthened by the fact that adverse inferences have been permitted against a silent defendant who, despite being granted an intermediary to help give evidence, had no such assistance at his trial. ${ }^{189}$ Expecting defendants to actively participate when they do not feel that they are in a position to do so meaningfully, and then penalising their failure to participate, provides a key example of the way in which the defendant's position as the autonomous subject of the proceedings has been disregarded.

Increasing recognition among academics, practitioners and policymakers, that more can and should be done to support vulnerable defendants is to be welcomed. ${ }^{190}$ While not always sufficient, special measures can enable some defendants to better engage in a dialogue with the court, challenge the prosecution case, and understand the basis for conviction or acquittal. If we appreciate the defendant's status as the subject of criminal proceedings and as someone who should be taken seriously, then we have reason to do all that we can to facilitate their participation. Consequently, formal eligibility criteria for special measures should be relaxed, such that defendants are eligible for assistance on at

\footnotetext{
187 A Owusu-Bempah, 'Vulnerable defendants and the right to silence: O'Donnell v United Kingdom [2015] ECHR 16667/10' (2015) 79 Journal of Criminal Law 322, 324.

${ }^{188}$ See, for example, $R v D$, above n 185; O'Donnell $v U K$, above $\mathrm{n} 186 ; R v$ Mulindwa [2017] EWCA Crim 416. ${ }^{189} R v$ Biddle, above $\mathrm{n} 161$. The Court was not convinced that there was a causative link between the defendant's silence and the absence of an intermediary. Also, note that if the court finds that special measures are necessary to ensure a fair trial, but the measures cannot be put in place, the proceedings should be stayed as an abuse of process. See $R v$ Akhtar [2016] EWCA Crim 390.

${ }_{190}$ See, for example, The Bradley Report, above n 152, p 61; Talbot, above n 5, p 3; Lord Carlile, above n 84, p 28; Law Commission, above n 5, paras 2.21-2.94; Justice, above n 152, pp 101-102; Plotnikoff and Woolfson, above $\mathrm{n} 182$, ch 5.8 .
} 
least the same basis as other witnesses. Relaxing eligibility requirements should be accompanied by an increase in resources for special measures, alongside effective procedures for identifying those who could benefit from assistance. At the same time, however, special measures and trial adjustments must not be viewed as a catch-all solution that can enable effective participation in every case, and those who choose not to give evidence should not face adverse inferences being drawn against them. To achieve a position in which effective and meaningful participation can be facilitated, but not forced, greater appreciation must be had for the rationales which underpin participatory rights, with special measures and trial adjustments viewed as one means of giving effect to those rationales.

\section{TAKING PARTICIPATORY RIGHTS SERIOUSLY}

It has been argued that the function of the criminal trial is to call the state to account for the accusations made against the defendant, before the defendant is subjected to condemnation and punishment. During this process of proof, the defendant should be treated as the subject, and not the object, of the proceedings. This is because, as an autonomous member of a liberal polity, the defendant is inherently worthy of dialogue. To treat the defendant as the subject of the proceedings is to respect them as a participant, ${ }^{191}$ which means giving effect to participatory rights, and providing a forum in which those rights can be exercised effectively. It also means listening to what the defendant has to say and taking their contributions seriously. Unfortunately, this normative account is not adequately reflected in current practice. While some defendants have sufficient experience or capacity to engage in the court process, it is seemingly more common for defendants to feel confused or excluded. Where effort is made to enable defendants to exercise their participatory rights, it tends to be focussed on those who are deemed to be vulnerable. Yet, the current regime of special measures and trial adjustments for vulnerable defendants suffers from serious limitations.

To facilitate meaningful participation, the court process and the court environment must become more accessible and hospitable. While many legal professionals seek to empathetically engage

191 Duff et al, above n 41, p 153. 
with defendants, there remains an obvious need to better, and more consistently and systemically, incorporate the principles of procedural justice, as advocated above. We should strive to enable all defendants to understand what is happening and why, and feel included and able to exercise their participatory rights. In pursuit of this goal, some simple changes have been advocated, including: a less restrictive application of the right to effective participation; a more diverse and representative legal profession; dispensing with antiquated legal language and speaking in a clear and simple manner throughout court proceedings; allowing defendants to sit near their legal representatives; and better provision of special measures for vulnerable defendants.

It is unlikely that these developments would result in complete understanding or engagement of all defendants. For some, disengagement from the court process may be rooted in underlying problems of social exclusion and dissatisfaction. For others, it may be in their best interest to take a passive role and allow their legal representative to present their case. ${ }^{192}$ Still, changes to law, practice and court culture could make a significant difference for many defendants. Given the simple and straightforward nature of most of the proposals, the fact that some have already been adopted in respect of vulnerable witnesses, ${ }^{193}$ and the fact that influential campaign groups continue to advocate for change, ${ }^{194}$ we must return to the question of why significant barriers to the meaningful participation of defendants in court continue to exist. Part of the explanation could be lack of resources, as facilitating meaningful and effective participation is likely to clash with the current focus on efficiency. However, it is submitted that the primary explanation is lack of regard for the rationales for participatory rights. Too often defendant participation is viewed primarily as a means of efficient fact-finding, with defendants well placed to help with early identification of the 'real issues' in the case, ${ }^{195}$ as well as provide relevant evidence. This has resulted in the imposition of penalties against those who do not actively participate when called upon to do so. Thus, while it is possible to improve meaningful communication by and with defendants, this depends on a broader change in perspective among those

\footnotetext{
192 For example, where the defendant is liable to incriminate themselves.

193 Though there are problems with the implementation of measures and adjustments for non-defendant witnesses. See, for example, Plotnikoff and Woolfson, above n 182.

194 See, for example, Justice, above n 109, p 67.

195 As is required of the court under CrimPR 3.2(2)(a).
} 
who make and apply the law and procedure. Respect for individual dignity and autonomy requires that we do not oblige defendants to actively participate in proceedings against themselves, but, at the same time, provide an opportunity to do so. For those who would prefer to focus on the instrumental benefits of facilitating meaningful participation, it is worth reiterating that giving a voice to those most affected by the criminal process enhances the legitimacy of the process and the outcome of trials. 